\title{
White blood cell count and the risk of coronary heart disease and all-cause mortality in elderly men.
}

Citation for published version (APA):

Weijenberg, M. P., Feskens, E., \& Kromhout, D. (1996). White blood cell count and the risk of coronary heart disease and all-cause mortality in elderly men. Arteriosclerosis Thrombosis and Vascular Biology, 16, 499-503. https://doi.org/10.1161/01.ATV.16.4.499

Document status and date:

Published: 01/01/1996

DOI:

10.1161/01.ATV.16.4.499

Document Version:

Publisher's PDF, also known as Version of record

Document license:

Taverne

\section{Please check the document version of this publication:}

- A submitted manuscript is the version of the article upon submission and before peer-review. There can be important differences between the submitted version and the official published version of record.

People interested in the research are advised to contact the author for the final version of the publication, or visit the DOI to the publisher's website.

- The final author version and the galley proof are versions of the publication after peer review.

- The final published version features the final layout of the paper including the volume, issue and page numbers.

Link to publication

\footnotetext{
General rights rights.

- You may freely distribute the URL identifying the publication in the public portal. please follow below link for the End User Agreement:

www.umlib.nl/taverne-license

Take down policy

If you believe that this document breaches copyright please contact us at:

repository@maastrichtuniversity.nl

providing details and we will investigate your claim.
}

Copyright and moral rights for the publications made accessible in the public portal are retained by the authors and/or other copyright owners and it is a condition of accessing publications that users recognise and abide by the legal requirements associated with these

- Users may download and print one copy of any publication from the public portal for the purpose of private study or research.

- You may not further distribute the material or use it for any profit-making activity or commercial gain

If the publication is distributed under the terms of Article $25 \mathrm{fa}$ of the Dutch Copyright Act, indicated by the "Taverne" license above, 


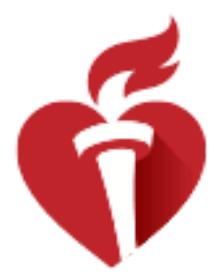

\title{
White Blood Cell Count and the Risk of Coronary Heart Disease and All- Cause Mortality in Elderly Men
}

\author{
M.P. Weijenberg, E.J.M. Feskens, and D. Kromhout
}

Abstract Because the importance of established risk factors for coronary heart disease (CHD) is unclear in older people, the associations of white blood cell (WBC) count with the risk for CHD and all-cause mortality were investigated in an elderly cohort that was followed up for 5 years. In 1985 , complete information on the risk factors of interest was available for 884 randomly selected men, aged 64 to 84 years, from the Dutch town of Zutphen (participation rate, 74\%). Relative risks (RRs) for each $10^{9} / \mathrm{L}$ increase in WBC count were obtained for the 5-year incidence of and mortality from CHD and all causes. RRs were adjusted for age, body mass index, systolic blood pressure, total and high density lipoprotein cholesterol levels, and cigarette smoking habit. The WBC count was $6.7 \pm 1.8 \times 10^{9} / \mathrm{L}$ (mean \pm SD) at baseline. An increased WBC count was independently associated with mortality due to CHD, and the RR amounted to $1.32(95 \%$ confidence interval $[95 \% \mathrm{Cl}], 1.15$ to 1.51$)$. For the incidence of $\mathrm{CHD}$ the RR was $1.14(95 \% \mathrm{Cl}$, 0.98 to 1.32). These associations were observed regardless of cigarette smoking habit. Regarding all-cause mortality, the RR amounted to $1.25(95 \% \mathrm{Cl}, 1.17$ to 1.35$)$. This association was especially noticeable among former smokers and those who had never smoked. In conclusion, during 5 years of follow-up WBC count predicted CHD and all-cause mortality in elderly men, independent of the conventional risk factors for CHD.

Key Words: white blood cell count a coronary heart disease a mortality a follow-up a elderly

pidemiological evidence is accumulating that implicates a moderately increased WBC count as a risk factor for CHD. ${ }^{12345678}$ Although the observed effect for the most part has often been ascribed to smoking, 237 biologic mechanisms for the association have also been described. ${ }^{9} 10$ Most evidence is based on studies of middle-aged people, 12345678 but little is known about the importance of WBC count in predicting CHD in the elderly. ${ }^{9}$

In general, there is much current debate regarding the importance of conventional risk factors for CHD in the elderly. ${ }^{11} 12$ Likewise, it can be questioned whether WBC count continues to predict $\mathrm{CHD}$ with advancing age. On the other hand, because there may be selective survival of elderly people with elevated levels of conventional risk factors, ${ }^{13}$ other factors such as the WBC count may assume greater importance. Because atherosclerosis is generally well advanced in the elderly, factors that are more specifically associated with thrombosis than with atherosclerosis may be more significant in predicting CHD in this age group. ${ }^{14}$ In the presence of atherosclerosis, 
activated monocytes and neutrophils may release products that promote plaque disruption and subsequent thrombus formation, which may eventually lead to a coronary event. ${ }^{10} 15$ We investigated whether an elevated WBC count might be associated with CHD and all-cause mortality in an elderly cohort that was followed up for 5 years.

\section{METHODS}

\section{Population}

Initiated in 1960, the Zutphen Study is a longitudinal investigation of chronic-disease risk factors among middle-aged men that was the Dutch contribution to the Seven Countries Study. ${ }^{16}$ In 1985 , 555 men from the 1960 cohort were still alive and were invited for new examinations. In addition, a random sample of all age-matched men (two of three) who were living in Zutphen and who were not part of the 1960 cohort were invited to take part in the study. From this point, the study was continued as the Zutphen Elderly Study. Of the 1266 men who were invited to participate, 939 $(74 \%)$ agreed. One hundred nine men (9\%) could not be examined because of serious illness or death, $62(5 \%)$ had moved from the area, and $156(12 \%)$ either refused to participate or could not be reached. Complete information on risk factors was available for 884 men aged 64 to 84 years.

\section{Examinations}

Physical examinations took place between March and June 1985 and were performed by five physicians who had been trained to follow a standardized protocol. Height was measured to the nearest $0.1 \mathrm{~cm}$ and body weight to the nearest $0.5 \mathrm{~kg}$ after the men had removed their shoes and outer garments. Body mass index (weight in kilograms divided by the square of height [in meters squared]) was calculated. At the end of the examination, systolic and diastolic (Korotkoff phase V) blood pressures were measured twice with a random-zero sphygmomanometer on the right arm while each subject was supine. The mean of the two blood pressure readings was used for analysis.

Nonfasting venous blood samples were taken. A Coulter S880 counter was used to determine WBC count and Hct. The coefficients of variation for within- and between-run measurement errors were $<2 \%$ for both WBC count and Hct. Serum total and HDL cholesterol levels were determined enzymatically with the CHOD-PAP monotest kit from Boehringer Mannheim. ${ }^{17} 18$ HDL was isolated after precipitation of apoB-containing particles by dextran sulfate- $\mathrm{Mg}^{2+}{ }^{19}$ The lipid analyses were carried out according to standardized protocols in the lipid laboratory of the Department of Human Nutrition, Agricultural University, Wageningen, the Netherlands. Serum albumin levels were analyzed in an autoanalyzer (SMAC, Technicon) on blood samples from 879 men.

Information on smoking habits was assessed by a standardized questionnaire for all but one participant. Information on the presence of diabetes mellitus, cancer, and chronic obstructive pulmonary disease at baseline was obtained through a standardized medical questionnaire during the physical examination and was verified by hospital discharge data and written information from the subjects' general practitioners.

\section{Follow-up}

Information on the prevalence and incidence of CHD was obtained during the physical examination in 1985 and during a similar examination in 1990. For men who did not participate in the 1990 examination, information on major chronic diseases was obtained from a questionnaire. 
CHD was considered to be present when either myocardial infarction or angina pectoris had been diagnosed. For myocardial infarction the final diagnosis was based on whether at least two of the following three criteria were met: (1) specific medical history, ie, severe chest pain lasting $>20$ minutes and not disappearing on rest; (2) characteristic electrocardiographic changes; and (3) specific enzyme elevations. The diagnosis of angina pectoris was based on information obtained from the Dutch translation of the Rose questionnaire. ${ }^{20}$ Additionally, all diagnoses were verified by information from electrocardiograms, hospital discharge data, and written information from the subjects' general practitioners. The information was coded by one physician, and the year of first diagnosis was recorded.

Information on the vital status of participants was obtained until July 1990. One man had moved abroad and was lost to follow-up. The date on which he moved was used as his censored end-point date. Information on causes of death was obtained from the Dutch Central Bureau of Statistics, after verification by hospital discharge data and information from the deceased's general practitioners. Causes of death were coded according to the ninth revision of the International Classification of Diseases (ICD), ${ }^{21}$ and both the primary and secondary cause of death were considered. Death due to CHD was defined by ICD codes 410 to 414 , death due to cardiovascular disease by codes 410 to 448 , death due to all-cause cancer by codes 140 to 239, and death due to lung cancer by code 162 .

The main end points were the incidence of a first (fatal or nonfatal) CHD event among men without the disease at baseline (ie, incidence of $\mathrm{CHD}$ ) and mortality from CHD and all causes.

\section{Statistical Methods}

Statistical analyses were carried out using the SAS program (SAS Institute Inc, 1989, version 6.07). All tests were two sided and values of $P<5 \%$ were considered significant. Cox's proportional-hazards (survival) analysis was carried out to investigate the associations of WBC count with the study end points during the 5 years of follow-up. ${ }^{22}$ The date on which an event occurred was used in the analyses. For CHD incidence July 1 of the year of diagnosis was used as the date of the event. RRs are presented according to a $10^{9} / \mathrm{L}$ increase in WBC count. Interaction terms were evaluated at the 10\% level. Quintiles of WBC count were formed and adjusted RRs for these quintiles were computed with the lowest category as the reference.

\section{RESULTS}

The WBC count at baseline ranged between 2.4 and $16.1 \times 10^{9} / \mathrm{L}$. WBC count was not significantly associated with baseline age or with most of the conventional risk factors for CHD (Table 1). There was an inverse association between WBC count and levels of HDL cholesterol and serum albumin and a positive association between WBC count and Hct. WBC count was higher in the 58 men with diabetes mellitus at baseline compared with men who were free of this disease (mean $\pm S D$, $7.1 \pm 1.8 \times 10^{9} / \mathrm{L}$ versus $6.6 \pm 1.8 \times 10^{9} / \mathrm{L}$ ). This difference was of borderline significance. WBC count was significantly higher in men who were cigarette smokers at baseline compared with former and never smokers $(P<.0001$; Table 2$)$. There was no significant difference in WBC count between former smokers who had quit $>10$ years ago and those who had quit $\leq 10$ years ago or between men who smoked differing amounts of cigarettes in 1985 (Table 2).

WBC count was not associated with the prevalence of $\mathrm{CHD}$ at baseline $\left(6.7 \pm 1.7 \times 10^{9} / \mathrm{L}\right.$ in 175 cases versus $6.6 \pm 1.8 \times 10^{9} / \mathrm{L}$ in noncases). However, in 21 men who suffered a CHD event within 6 
months before blood sampling, WBC count tended to be higher than that of men without any evidence of $\mathrm{CHD}$ at baseline $\left(7.0 \pm 1.4 \times 10^{9} / \mathrm{L}\right.$ compared with $6.6 \pm 1.8 \times 10^{9} / \mathrm{L}$, respectively; $\left.P=.10\right)$.

WBC count was positively and independently associated with mortality from CHD during the 5 years of follow-up (Table 3), and this association tended to be exponential (Figure). Additional adjustment for the presence of CHD at baseline did not affect the strength of the association (RR, $1.32 ; 95 \% \mathrm{Cl}, 1.13$ to 1.53 ). The association was of the same magnitude among the 793 men with WBC counts within the normal range of 4.5 to $11 \times 10^{9} / \mathrm{L}$ (not shown). The association of WBC count with the incidence of a first $\mathrm{CHD}$ event was also positive, although weaker than that with mortality due to CHD (adjusted RR, 1.14; $95 \% \mathrm{CI}, 0.98$ to 1.32).

WBC count was also independently associated with all-cause mortality (Table 3 ) in a graded fashion (Figure). This association persisted even after adjustment for the presence of major chronic diseases at baseline, such as cardiovascular diseases, cancer, and chronic obstructive pulmonary disease (RR, $1.15 ; 95 \% \mathrm{Cl}, 1.07$ to 1.24). Additional analyses revealed that WBC count was associated with an increased risk of death from all cardiovascular diseases (risk factor- and disease-adjusted RR, 1.21; $95 \% \mathrm{Cl}, 1.09$ to 1.34), cancer (adjusted RR, 1.10; 95\% Cl, 0.97 to 1.24 ), and all other causes (adjusted RR, 1.15; $95 \% \mathrm{Cl}, 0.98$ to 1.35).

The association of WBC count with CHD has often been ascribed to the effect of smoking on CHD. However, cigarette smoking status in 1985 was not significantly associated with mortality from either CHD ( $P$-trend=.64) or all causes $(P$-trend=.47) during 5 years of follow-up. Cigarette smoking was significantly associated with death due to lung cancer only $(P$-trend=.05). WBC count was positively associated with mortality from CHD regardless of cigarette smoking status (Table 4). This association tended to be stronger among men who had never smoked but was not significantly different from those of the men in the other smoking status categories. Regarding allcause mortality there was a significant association with WBC count among nonsmokers but not among current smokers ( $P$-interaction=.07).

\section{DISCUSSION}

This is the first report on the association between WBC count and CHD in elderly men. An increase of 1 SD in WBC count was associated with a $65 \%$ increase in the risk of death from CHD. This effect is considerably higher than the $45 \%$ increased risk that is associated with a $1-S D$ increase in the total cholesterol level in the same cohort during the same period. ${ }^{23}$ In studies of middle-aged people the effect of WBC count on CHD has been found to be similar to ${ }^{2}$ or even smaller than ${ }^{6} 8$ that of total cholesterol levels. These findings suggest that in advanced age, factors other than the conventional risk factors for CHD, such as WBCs, become more important in predicting disease.

Possible biologic mechanisms underlying the observed associations have been postulated. It is widely recognized that monocytes have a role in the pathogenesis of atherosclerosis. ${ }^{15}$ After monocytes are recruited at the site of endothelial injury, they adhere to the vessel wall, enter it, and are eventually converted into foam cells. Because the monocyte count constitutes $\approx 2 \%$ to $10 \%$ of the total WBC count, monocytes are probably not the only fraction of WBCs that are responsible for the observed association with CHD. Indeed neutrophils, the most common granulocyte, have also been implicated in the pathogenesis of atherosclerosis. ${ }^{10}$ In the presence of atherosclerosis, which can be viewed as an inflammatory disease, ${ }^{24}$ WBCs may become activated. This leads to reduced deformability of the neutrophilic cells in particular and WBC aggregation, adherence to the endothelium, and recruitment, all of which subsequently lead to 
capillary plugging and tissue ischemia. Activated neutrophils and monocytes may also release products that induce plaque rupture and subsequent thrombus formation, which can also result in ischemia. $^{10} 15$ The main products that are released by these cells are oxidants, such as superoxide radicals and NO, ${ }^{25}$ and proteolytic enzymes, ${ }^{10}$ all of which can induce vascular injury. Pathological mechanisms have also been postulated for the association between WBC count and diseases other than CHD. Oxidation metabolites that are produced by activated WBCs during inflammation may also be involved in the pathogenesis of cancer and lung disease. ${ }^{10}$

Because the WBC count is a general indicator of inflammation it may also be a marker for underlying atherothrombotic disease. The observed association with CHD is therefore not necessarily causal; which mechanisms underlie the association cannot be derived from this study.

In this study the association between WBC count and CHD incidence was weaker than that between WBC count and CHD mortality. Owing to plaque rupture and thrombus formation, WBC count may be more strongly associated with severe subsequently fatal CHD. ${ }^{15}$ This may also explain the baseline results, because there was no clear evidence that men with CHD at baseline had elevated WBC counts compared with men who were free of the disease. This was especially noticeable in those who were first diagnosed with $\mathrm{CHD}>6$ months before blood sampling. It is possible that men with elevated WBC counts and a long-term history of CHD had died before the baseline measurement. The elevated WBC counts in men who suffered a CHD event in the same year that blood samples were taken may have been due to active atherosclerosis, ie, progression of atherosclerosis.

WBC count also predicted all-cause mortality, which has previously been observed in middleaged populations. ${ }^{8} 26$ An elevated WBC count may be a marker for inflammation and is therefore also associated with an increased risk of mortality. Although the association between WBC count and all-cause mortality remained after adjustment for clinical diagnosis of major chronic diseases, possible underlying (subclinical) disease may have affected the observed association. Part of the association may be a consequence of the strong association between WBC count and CHD mortality.

The association between WBC count and CHD has at least partially been attributed to smoking. ${ }^{2} 37$ In the present study the positive association between WBC count and CHD was observed regardless of smoking status. WBC count predicted CHD and all-cause mortality in nonsmokers; thus, smoking status alone does not explain our findings.

Surprisingly, smoking status does not appear to be associated with CHD in the present study. Because most of the men in our study smoked during at least part of their lifetime, a larger population may be needed to examine this association. ${ }^{27}$ In addition, men who continued to smoke in advanced age and survived its detrimental effects might be less susceptible to such effects than those who did not reach old age. The smokers in this study may be a select group of healthy men, regardless of smoking habit, who are less susceptible to CHD. In a larger cohort study of older people, cigarette smoking is clearly associated with increased mortality outcomes and cessation of smoking is known to improve survival in the elderly. ${ }^{27}$ Therefore, caution is warranted in interpreting our findings regarding the risk of cigarette smoking.

In conclusion, WBC count appears to predict future CHD and mortality independent of conventional risk factors. WBC count is probably not only an indicator of clinical or subclinical disease but also a true risk factor for CHD. Whether a causal pathway is involved should be assessed in future experimental studies. Nevertheless, WBC count could be important in public health, because it is routinely measured by clinicians. Moreover, WBC count seems to be important in older people specifically, as it appears to be more strongly associated with CHD than are other conventional risk factors, such as total cholesterol, in this age group. 


\section{SELECTED ABBREVIATIONS AND ACRONYMS}

\begin{tabular}{|l|l|l|}
\hline $\mathrm{CHD}$ & $=$ & coronary heart disease \\
\hline $\mathrm{Cl}(\mathrm{s})$ & $=$ & confidence interval(s) \\
\hline $\mathrm{Hct}$ & $=$ & hematocrit \\
\hline $\mathrm{RR}(\mathrm{s})$ & $=$ & relative risk(s) \\
\hline $\mathrm{WBC}(\mathrm{s})$ & $=$ & white blood cell(s) \\
\hline
\end{tabular}

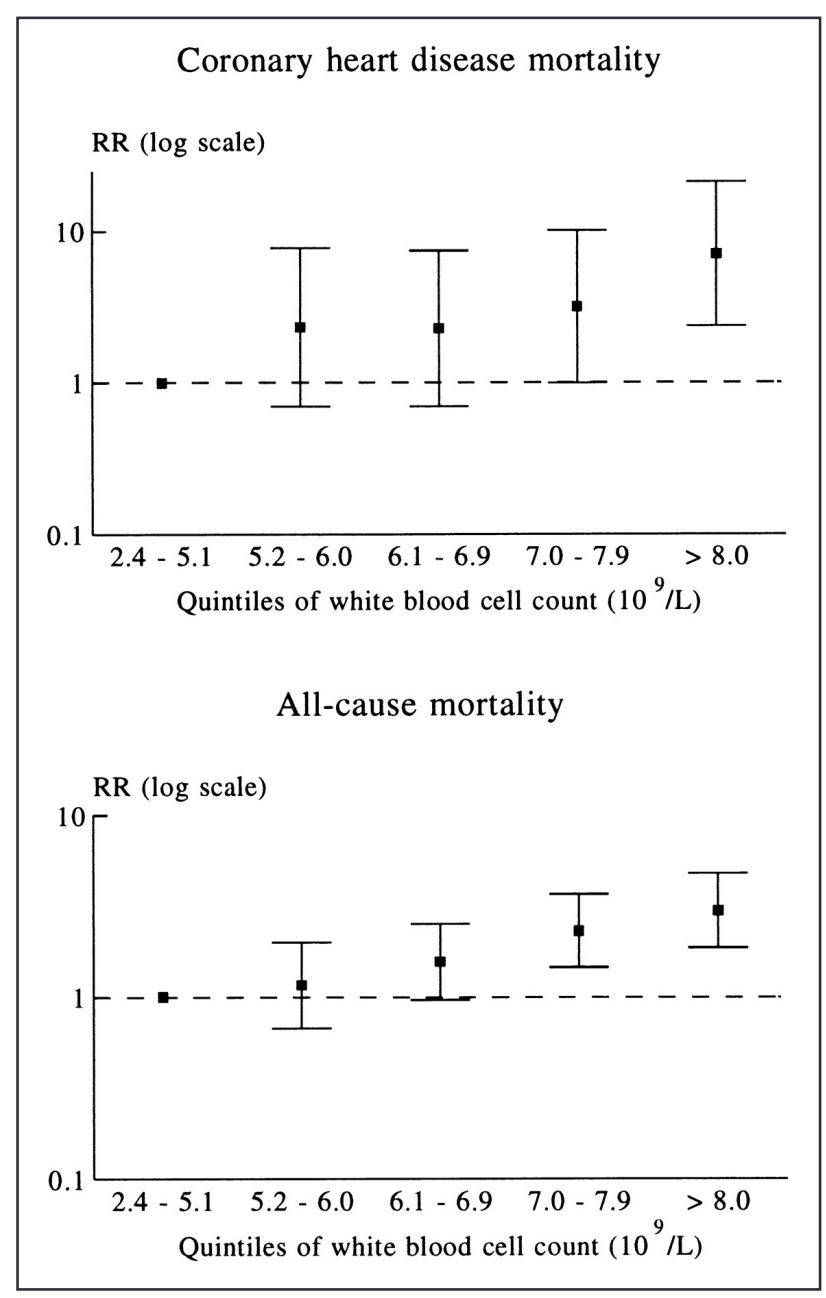

Figure 1. RRs and $95 \%$ Cls for mortality from CHD and from all causes according to quintiles of WBC count.

Table 1. Population Characteristics and Associations With WBC Count in 884 Men Aged 64-84 Years: The Zutphen Elderly Study, 1985 (Table view)

\begin{tabular}{|l|l|l|}
\hline Variable & Mean $\pm \mathrm{SD}^{1}$ & Spearman Correlation Coefficient With WBC Count \\
\hline WBC count, $\times 10^{9} / \mathrm{L}$ & $6.7 \pm 1.8$ & $\ldots$ \\
\hline Age, $\mathrm{y}$ & $71.5 \pm 5.3$ & -.01 \\
\hline Body mass index, $\mathrm{kg} / \mathrm{m}^{2}$ & $25.45 \pm 3.20$ & -.00 \\
\hline Systolic blood pressure, $\mathrm{mm} \mathrm{Hg}$ & $151.0 \pm 21.5$ & .03 \\
\hline Diastolic blood pressure, $\mathrm{mm} \mathrm{Hg}$ & $85.4 \pm 11.5$ & -.01 \\
\hline Serum total cholesterol, $\mathrm{mmol} / \mathrm{L}$ & $6.10 \pm 1.11$ & .01 \\
\hline Serum HDL cholesterol, $\mathrm{mmol} / \mathrm{L}$ & $1.12 \pm 0.29$ & $-.08^{2}$ \\
\hline Serum albumin, $\mathrm{g} / \mathrm{L}$ & $44.1 \pm 2.7$ & $-.14^{3}$ \\
\hline Hct & $0.45 \pm 0.04$ & $.12^{3}$ \\
\hline
\end{tabular}




\begin{tabular}{|l|l|l|}
\hline Variable & Mean $\pm \mathrm{SD}^{1}$ & Spearman Correlation Coefficient With WBC Count \\
\hline Diabetes mellitus, $\mathrm{n}(\%)$ & $58(6.6)$ & $.07^{4}$ \\
\hline
\end{tabular}

1 All values are mean $\pm \mathrm{SD}$, except where noted otherwise.

$2 P<.05$,

$3 P<.001$,

$4 P=$ NS for the Mann-Whitney $U$ test of the difference in mean WBC count between those with and those without diabetes mellitus.

Table 2. Mean WBC Count According to Cigarette Smoking Habit in Elderly Men: The Zutphen Elderly Study, 1985 (Table view)

\begin{tabular}{|l|l|l|}
\hline Cigarette Smoking Habit in 1985 & $\mathrm{n}$ & WBC Count, $\times 10^{9} / \mathrm{L}$ \\
\hline Never smoker & 162 & $6.4 \pm 1.7^{1}$ \\
\hline Former smoker & 454 & $6.3 \pm 1.7^{1}$ \\
\hline$>10$ Years ago & 268 & $6.2 \pm 1.6$ \\
\hline$\leq 10$ Years ago & 168 & $6.5 \pm 1.9$ \\
\hline Current smoker & 267 & $7.3 \pm 1.8^{1}$ \\
\hline $1-9$ Cigarettes/d & 63 & $7.2 \pm 1.9$ \\
\hline $10-19$ Cigarettes/d & 111 & $7.3 \pm 1.7$ \\
\hline$\geq 20$ Cigarettes/d & 92 & $7.5 \pm 1.8$ \\
\hline
\end{tabular}

1 Overall Kruskal-Wallis test comparing never, former, and current smokers: $P<.0001$.

Table 3. RRs for Mortality From CHD and All Causes Associated With WBC Count in Elderly Men: The Zutphen Elderly Study, 1985 (Table view)

\begin{tabular}{|c|c|c|}
\hline & $\mathrm{CHD}^{1}$ & All Causes ${ }^{1}$ \\
\hline No. of/percent deaths & $53 / 6$ & $211 / 24$ \\
\hline Crude RR & $1.27(1.11-1.44)$ & $1.20(1.12-1.28)$ \\
\hline RR adjusted for age & $1.30(1.14-1.49)$ & $1.24(1.15-1.33)$ \\
\hline RR adjusted for conventional risk factors ${ }^{2}$ & $1.32(1.15-1.51)$ & $1.25(1.17-1.35)$ \\
\hline RR adjusted for additional risk factors ${ }^{3}$ & $1.27(1.10-1.46)$ & $1.21(1.12-1.30)$ \\
\hline
\end{tabular}

1 All values are presented as the RR and $(95 \% \mathrm{Cl})$ for each $10^{9} / \mathrm{L}$ increase in WBC count, except where noted otherwise.

2 Age, body mass index, systolic blood pressure, total cholesterol, HDL cholesterol, and cigarette smoking.

3 Conventional risk factors and serum albumin, $\mathrm{Hct}$, and diabetes mellitus at baseline.

Table 4. RRs for Mortality From CHD and All Causes Associated With WBC Count in Elderly Men According to Smoking Status at Baseline: The Zutphen Elderly Study, 1985 (Table view)

\begin{tabular}{|c|c|c|c|c|c|c|}
\hline & \multicolumn{6}{|c|}{ Smoking Status in 1985} \\
\hline & \multicolumn{3}{|l|}{$\mathrm{CHD}$} & \multicolumn{3}{|l|}{ All Causes } \\
\hline & $\begin{array}{l}\text { Never } \\
(n=162)\end{array}$ & $\begin{array}{l}\text { Former } \\
(\mathrm{n}=454)\end{array}$ & $\begin{array}{l}\text { Current } \\
(n=267)\end{array}$ & $\begin{array}{l}\text { Never } \\
(n=162)\end{array}$ & $\begin{array}{l}\text { Former } \\
(n=454)\end{array}$ & $\begin{array}{l}\text { Current } \\
(\mathrm{n}=267)\end{array}$ \\
\hline No. of/percent deaths & $9 / 5.6$ & $25 / 7.2$ & $22 / 8.2$ & $40 / 24.5$ & $106 / 23.4$ & $65 / 24.3$ \\
\hline Crude RR & $\begin{array}{l}1.47(1.10- \\
1.96)^{1}\end{array}$ & $\begin{array}{l}1.28(1.07- \\
1.53)\end{array}$ & $\begin{array}{l}1.21(0.94- \\
1.56)\end{array}$ & $\begin{array}{l}1.28(1.10- \\
1.40)\end{array}$ & $\begin{array}{l}1.29(1.18- \\
1.41)\end{array}$ & $\begin{array}{l}1.05(0.92 \\
1.20)\end{array}$ \\
\hline RR adjusted for age & $\begin{array}{l}1.47(1.10- \\
1.95)\end{array}$ & $\begin{array}{l}1.32(1.09- \\
1.59)\end{array}$ & $\begin{array}{l}1.26(0.97- \\
1.63)\end{array}$ & $\begin{array}{l}1.28(1.10- \\
1.49)\end{array}$ & $\begin{array}{l}1.33(1.21- \\
1.46)\end{array}$ & $\begin{array}{l}1.09(0.95 \\
1.25)\end{array}$ \\
\hline
\end{tabular}




\begin{tabular}{|c|c|c|c|c|c|c|}
\hline & \multicolumn{6}{|c|}{ Smoking Status in 1985} \\
\hline & \multicolumn{3}{|l|}{$\mathrm{CHD}$} & \multicolumn{3}{|l|}{ All Causes } \\
\hline & $\begin{array}{l}\text { Never } \\
(n=162)\end{array}$ & $\begin{array}{l}\text { Former } \\
(\mathrm{n}=454)\end{array}$ & $\begin{array}{l}\text { Current } \\
(n=267)\end{array}$ & $\begin{array}{l}\text { Never } \\
(n=162)\end{array}$ & $\begin{array}{l}\text { Former } \\
(n=454)\end{array}$ & $\begin{array}{l}\text { Current } \\
(\mathrm{n}=267)\end{array}$ \\
\hline $\begin{array}{l}\text { RR adjusted for conventional } \\
\text { risk factors }{ }^{2}\end{array}$ & $\begin{array}{l}1.51(1.10- \\
2.08)\end{array}$ & $\begin{array}{l}1.30(1.07- \\
1.59)\end{array}$ & $\begin{array}{l}1.20(0.90- \\
1.59)\end{array}$ & $\begin{array}{l}1.29(1.10- \\
1.51)\end{array}$ & $\begin{array}{l}1.33(1.20- \\
1.47)\end{array}$ & $\begin{array}{l}1.05(0.91 \\
1.22) \\
\end{array}$ \\
\hline $\begin{array}{l}\text { RR adjusted for additional } \\
\text { risk factors }{ }^{3}\end{array}$ & $\begin{array}{l}1.56(1.13- \\
2.16)\end{array}$ & $\begin{array}{l}1.24(1.00- \\
1.54)\end{array}$ & $\begin{array}{l}1.27(0.92- \\
1.74)\end{array}$ & $\begin{array}{l}1.27(1.09- \\
1.49)\end{array}$ & $\begin{array}{l}1.26(1.13- \\
1.40)\end{array}$ & $\begin{array}{l}1.05(0.91 \\
1.22)\end{array}$ \\
\hline
\end{tabular}

1 All values are presented as the RR (and $95 \% \mathrm{Cl}$ ) for each $10^{9} / \mathrm{L}$ increase in WBC count.

2 Age, body mass index, systolic blood pressure, total cholesterol, HDL cholesterol, and cigarette smoking.

3 Conventional risk factors and serum albumin, Hct, and diabetes mellitus at baseline.

\section{ARTICLE INFORMATION}

Received October 2, 1995; accepted January 12, 1996.

\section{Note}

Reprints requests to Matty P. Weijenberg, MSc, Department of Chronic Diseases and Environmental Epidemiology, National Institute of Public Health and Environmental Protection, PO Box 1, 3720 BA Bilthoven, Netherlands. E-mail m.weijenberg@rivm.nl.

\section{Affiliations}

From the Department of Chronic Diseases and Environmental Epidemiology, National Institute of Public Health and Environmental Protection, Bilthoven, the Netherlands. .

\section{Acknowledgments}

This study was supported by grants from the Netherlands Prevention Foundation and the National Institute on Aging, National Institutes of Health, Bethesda, Md. We thank the fieldwork team in Zutphen, especially Drs E.B. Bosschieter and B.P.M. Bloemberg; the Laboratory of Clinical Chemistry and Haematology of the Nieuw Spitaal Hospital in Zutphen, especially Dr K. Jaspers (head) and A. Hulleman for the determination of WBC count and Hct; C. de Lezenne Coulander, MSc, for data management; and I. Miedema, MSc, and Dr S. Keli for coding the incidence and mortality data.

\section{REFERENCES}

1. Yarnell JWG, Baker IA, Sweetnam PM, Bainton D, O'Brien JR, Whitehead PJ, Elwood PC. Fibrinogen, viscosity, and white blood cell count are major risk factors for ischemic heart disease: the Caerphilly and Speedwell Collaborative Heart Disease Studies. Circulation. 1991;83:836-844. Crossref. PubMed.

2. Friedman GD, Klatsky AL, Siegelaub AB. The leukocyte count as a predictor of myocardial infarction. $N$ Engl J Med. 1974;290:1275-1278. Crossref. PubMed.

3. Zalokar JB, Richard JL, Claude JR. Leukocyte count, smoking and myocardial infarction. N Engl J Med. 1981;304:465-468. Crossref. PubMed.

4. Olivares R, Ducimetière $P$, Claude JR. Monocyte count: a risk factor for coronary heart disease? Am J Epidemiol. 1993;137:49-53. Crossref. PubMed.

5. Kannel WB, Anderson K, Wilson PWF. White blood cell count and cardiovascular disease: insights from the Framingham Study. JAMA. 1992;267:1253-1256. Crossref. PubMed.

6. Phillips AN, Neaton JD, Cook DG, Grimm RH, Shaper AG. Leukocyte count and risk of major coronary heart disease events. Am J Epidemiol. 1992;136:59-70. Crossref. PubMed. 
7. Gillum RF, Ingram DD, Makuc DM. White blood cell count, coronary heart disease, and death: the NHANES I Epidemiologic Follow-up Study. Am Heart J. 1993;125:855-863. Crossref. PubMed.

8. Grimm RH, Neaton JD, Ludwig W. Prognostic importance of the white blood cell count for coronary, cancer, and all-cause mortality. JAMA. 1985;254:1932-1937. Crossref. PubMed.

9. Ensrud K, Grimm RH. The white blood cell count and risk for coronary heart disease. Am Heart J. 1992;124:207-213. Crossref. PubMed.

10. Ernst E, Hammerschmidt DE, Bagge U, Matrai A, Dormandy JA. Leukocytes and the risk of ischemic diseases. JAMA. 1987;257:2318-2324. Crossref. PubMed.

11. Manolio TA, Pearson TA, Wenger NK, Barrett-Connor E, Payne GH, Harlan WR. Cholesterol and heart disease in older persons and women: review of an NHLBI workshop. Ann Epidemiol. 1992;2:161-176. Crossref. PubMed.

12. Bulpitt CJ, Fletcher AE. Prognostic significance of blood pressure in the very old: implications for the treatment decision. Drugs Aging. 1994;5:184-191. Crossref. PubMed.

13. Kaplan GA, Haan MN, Cohen RD. Risk factors and the study of prevention in the elderly: methodological issues. In: Wallace RB, Woolson RF, eds. The Epidemiologic Study of the Elderly. New York, NY: Oxford University Press; 1992:20-36.

14. Barth JD, Arntzenius AC. Progression and regression of atherosclerosis, what roles for LDL-cholesterol and HDL-cholesterol: a perspective. Eur Heart J. 1991;12:952-957. Crossref. PubMed.

15. Fuster V, Lewis A. Conner Memorial Lecture: mechanisms leading to myocardial infarction-insights from studies of vascular biology. Circulation. 1994;90:2126-2146. Crossref. PubMed.

16. Keys A, Aravanis C, Blackburn HW, van Buchem FSP, Buzina R, Djordjevid BS, Dontas AS, Fidanza F, Karvonen MJ, Kimura N, Lekos D, Monti M, Puddu V, Taylor HL. Epidemiological studies related to coronary heart disease: characteristics of men aged 40-59 in seven countries. Acta Med Scand. 1967;460(suppl):1-392.

17. Siedel J, Schlumberger H, Klose S, Ziegenhorn J, Wahlefeld AW. Improved reagent for the enzymatic determination of serum cholesterol. J Clin Chem Clin Biochem. 1981;19:838-839.

18. Stähler F, Gruber W, Stinshoff K, Röschlau P. Eine praxisgerechte enzymatische cholesterinbestimmung. Med Lab. 1977;30:29-37. PubMed.

19. Warnick GR, Benderson J, Albers JJ. Dextran sulfate- $\mathrm{Mg}^{2+}$ precipitation procedure for quantitation of high-density-lipoprotein cholesterol. Clin Chem. 1982;28:1379-1388. Crossref. PubMed.

20. Rose GA, Blackburn H. Cardiovascular Survey Methods. Geneva, Switzerland: World Health Organization; 1968.

21. World Health Organization. Manual of the International Statistical Classification of Diseases, Injuries, and Causes of Death, 1975 (Ninth) Revision. Geneva, Switzerland: World Health Organization; 1977.

22. SAS Technical Report P-217, SAS/STAT® Software: The PHREG Procedure. version 6. Cary, NC: SAS Institute Inc; 1991.

23. Weijenberg MP, Feskens EJM, Kromhout D. Total and high density lipoprotein cholesterol as risk factors for coronary heart disease in elderly men during five years of follow-up: the Zutphen Elderly Study. Am J Epidemiol.. 1996;143:151-158. Crossref. PubMed.

24. Alexander RW. Inflammation and coronary artery disease. N Engl J Med. 1994;331:468-469. Crossref. PubMed.

25. Änggård E. Nitric oxide: mediator, murderer, and medicine. Lancet. 1994;343:1199-1206. Crossref. PubMed.

26. De Labry LO, Campion EW, Glynn RJ, Vokonas PS. White blood cell count as a predictor of mortality: results over 18 years from the Normative Aging Study. J Clin Epidemiol. 1990;43:153-157. Crossref. PubMed.

27. LaCroix AZ, Lang J, Scherr P, Wallace RB, Cornoni-Huntley J, Berkman L, Curb D, Evans D, Hennekens 
$\mathrm{CH}$. Smoking and mortality among older men and women in three communities. $N$ Engl $J$ Med. 1991;324:1619-1625. Crossref. PubMed. 